\title{
Recombinant fusion protein
} of Heparin-Binding Hemagglutinin Adhesin and Fibronectin Attachment Protein (rHBHA-FAP) of Mycobacterium avium subsp. paratuberculosis elicits a strong gamma interferon response in peripheral blood mononuclear cell culture

Vida Eraghi ${ }^{1}$, Abdollah Derakhshandeh ${ }^{1 *}$ (D), Arsalan Hosseini ${ }^{1}$, Masoud Haghkhah', Leonardo A. Sechi ${ }^{2}$ and Azar Motamedi Boroojeni ${ }^{1}$

\begin{abstract}
Background: Mycobacterium avium subsp. paratuberculosis (MAP) is a causative agent of Johne's disease in all ruminants worldwide. Economic problems in dairy cattle and sheep industries, public health concern, persistence of MAP in the environment and lack of effective vaccines mentioned necessity of research about various antigens to introduce as vaccine candidates. Based on MAP pathogenesis, it seems that research about the production of new recombinant proteins to stimulate cell-mediated immunity is helpful. This study describes successful expression and purification of a chimeric fusion protein which consists of Heparin-Binding Hemagglutinin Adhesin (HBHA) and high antigenic region of Fibronectin Attachment Protein (FAP-P). Triggered antigen-specific IFN- $\gamma$ response of isolated PBMCs from immunized goats to rHBHA-FAP and all crude proteins of MAP (PPD), was measured by ELISA.

Results: Significant increases were observed in the IFN- $\gamma$ production level of peripheral blood mononuclear cells (PBMCs) stimulated by constructed chimeric protein from rHBHA-FAP and PPD vaccinated goats. Antigen-specific gamma interferon (IFN- $\gamma$ ) secretion in positive group (immunized by PPD) against rHBHA-FAP and test group (immunized by rHBHA-FAP) against PPD, also statistically insignificant rises between stimulation with rHBHA-FAP and PPD, suggested the potential and specificity of our chimeric protein to stimulate cell mediated immunity against MAP.

Conclusions: Collectively, these results demonstrate that rHBHA-FAP elicits a strong IFN- $\gamma$ production in PBMC culture. Therefore, further studies of the present product as a candidate vaccine in naturally infected animals should be conducted, to analyze its potential.
\end{abstract}

Keywords: Mycobacterium avium subsp. paratuberculosis, Johne's disease, Chimeric protein, PBMC, IFN- $\gamma$

\footnotetext{
*Correspondence: drkhshnd77@gmail.com

${ }^{1}$ Department of Pathobiology, School of Veterinary Medicine, Shiraz

University, Shiraz 71345-1731, Iran

Full list of author information is available at the end of the article
} 


\section{Background}

The causative agent of Johne's disease in all ruminant species worldwide is Mycobacterium avium subsp. paratuberculosis (MAP). Chronic untreatable granulomatous enteritis in Johne's disease leads to economic problems in dairy cattle and sheep industries that result in decreased milk, diarrhea, and weight loss [1,2].

Although, MAP as a zoonotic pathogen has not yet been confirmed, there is some investigations about the role of MAP in public health concern. MAP can be isolated from pasteurized milk [3], children's milk powder [4], soil and surface water [5]. Also, MAP may shed through infected animal's feces and survive in the environment for a long period. Then the exposure of human to a contaminated environment is a potential risk [6]. There are studies about the association of MAP with Crohn's disease [7], sarcoidosis and Blau syndrome [8], type 1 diabetes [9], Hashimoto's thyroiditis [10], and multiple sclerosis (MS) [11]. This could explain the significant risk of MAP to public health safety. Among the approaches to reduce Johne's disease in most countries, testing and culling practices are the most common [12], but vaccination is the best control strategy and more cost-effective [13] than other approaches. Whole-cell based vaccines, live attenuated vaccines, and inactivated vaccines were have been used until now [12] with inadequate protection. $M$. avium subsp. paratuberculosis binds to Microfold cells (M cells) and epithelial cells through a fibronectin bridge and mycobacterial adhesins, to cross the intestinal barrier and enter into the subepithelium. Then, MAP can be picked up by antigen presenting cells and carried to regional lymph nodes [14]. IFN- $\gamma$ induced by $\mathrm{Th}_{1}$-mediated immune responses are play a crucial role in activating macrophages to kill intracellular MAP and protection against MAP infection $[15,16]$. Gamma interferon (IFN- $\gamma$ ) response and antibody response can be induced by MAP. IFN- $\gamma$ responses (mediated by $\mathrm{Th}_{1}$ ) detected early can lead to the controlling of MAP replication and restricted bacterial shedding; but antibody responses (mediated by $\mathrm{Th}_{2}$ ) detected late in infection which inhibit $\mathrm{Th}_{1}$ and are much less effective against MAP $[15,17,18]$. The best characterized mycobacterial adhesin is Heparin-binding hemagglutinin (HBHA). HBHA is located on the surface of mycobacteria and is important in the binding of mycobacteria to the epithelial cells [19] during bovine tuberculosis and Johne's disease; it is also a major target for host humoral immune response. Some studies have demonstrated that methylated HBHA causes specific IFN- $\gamma$ response in latent $M$. tuberculosis infection $[20,21]$. Also, there is some reports about the induction by HBHA of both $\mathrm{CD}^{+}$and $\mathrm{CD} 8^{+} \mathrm{T}$ lymphocytes producing cytokines like IFN- $\gamma$ in $M$. tuberculosis infection
[22, 23]. The FN-binding glycoprotein family including fibronectin attachment proteins (FAPs) is important for attachment and internalization of MAP by epithelial cells and induce $\mathrm{Th}_{1}$ polarization and IFN- $\gamma$ production in vitro [24].

Due to the global distribution of paratuberculosis and the creation of many economic problems, as well as suspicion of zoonotic nature of the MAP, using control strategies and research to identify appropriate antigens and introduce them as vaccine candidates are important. This study describes successful expression, purification, and evaluation of cellular immune response induction ability of a chimeric fusion protein which consists of HBHA and high antigenic region of FAP-P. Triggered antigen-specific IFN- $\gamma$ response of isolated PBMCs from immunized goats (with our chimeric fusion protein and the crude protein fraction prepared from the culture supernatant of MAPPPD) to rHBHA-FAP and PPD, was measured by ELISA.

\section{Results}

\section{Plasmid construction and cloning}

The designed chimeric gene consists of the HBHA-coding sequence, (Pro Glu) ${ }_{7}$ as a linker, and high antigenic region of FAP-P (amino acid 125 to 205) was synthesized and inserted in pUC57 between restriction sites of EcoRI and HindIII by GenScript company (USA). The transformation and propagation of the plasmid in E. coli DH5 $\alpha$ was done successfully.

\section{Successful expression and purification of rHBHA-FAP in $E$. coli BL21 (DE3)}

The fusion gene was successfully subcloned into the pET26b, transformed into E. coli BL21 (DE3), and confirmed by colony PCR. The expression of the chimeric protein is shown in Fig. 1. The desired fusion protein was determined in the medium induced by $1 \mathrm{mM}$ IPTG at $37{ }^{\circ} \mathrm{C}$ after $4 \mathrm{~h}$ of induction and the expected size of $\sim 35 \mathrm{kDa}$ was obtained. Expression levels after overnight incubation or increasing IPTG did not increase significantly. Using monoclonal anti-polyhistidine-peroxidase, the desired band obtained was confirmed to be the HBHA-FAP chimeric protein by immunoblotting (Fig. 1).

Binding of polyhistidine-tagged proteins with resin was performed using Ni-NTA column (Qiagen) and desired chimeric protein was then passed over the column with elution buffer. Using imidazole in binding buffer reduced the number of proteins that bind nonspecifically to the resin; also, using Tween and 2-mercaptoethanol reduced the background signals. Purified fractions were run on a $12 \%$ SDS-PAGE gel as to check the purity of the protein extracts. 


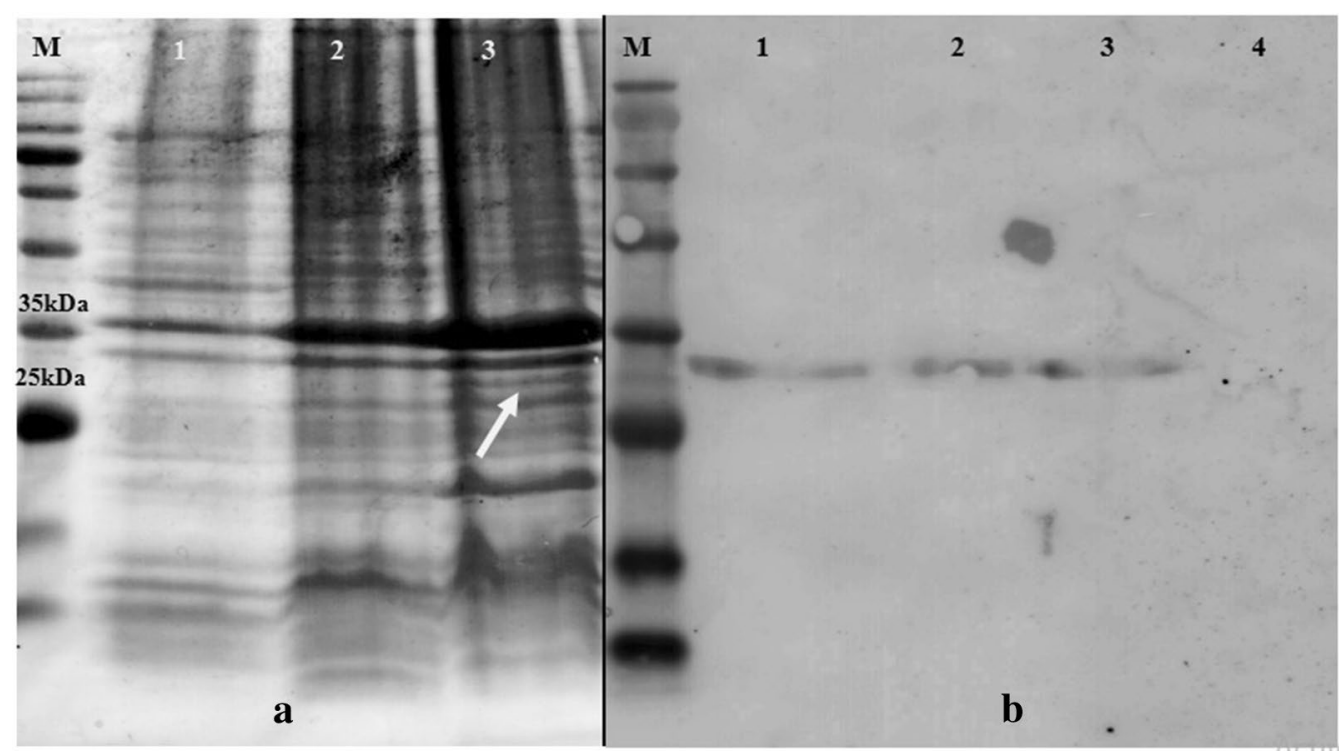

Fig. 1 SDS-PAGE (a) and western blot (b) of chimeric rHBHA-FAP. a Running samples on 12\% SDS-PAGE gel for choosing optimum temperature of rHBHA-FAP expression in E. coli. Lane M: protein ladder (CinnaGen PR911654 [SL7012]), lane 1: negative control, lane 2: expression at $30^{\circ} \mathrm{C}$, lane 3 : expression at $37^{\circ} \mathrm{C}$. The white arrow indicates our desired band. b Western blot analysis using HRP-anti-polyhistidine. Lanes 1, 2 and 3: rHBHA-FAP with the expected size of $\sim 35 \mathrm{kDa}$, lane 4: negative control

\section{IFN- $\gamma$ response}

Evaluation of cell mediated immune response to the chimeric protein was done by measuring antigen specific IFN- $\gamma$ responses. The high level of secreted IFN- $\gamma$ in supernatants of PBMCs in $96 \mathrm{~h}$ after incubation was detected. Therefore, the levels of secreted IFN- $\gamma$ in $96 \mathrm{~h}$ after incubation were recorded in the charts. The highest level of IFN- $\gamma$ was measured in supernatants of PBMCs stimulated by PHA in all groups, which indicates the ability of stimulated T-calls to secrete significant high level of IFN- $\gamma$.

Although there was no significant difference in induction of IFN- $\gamma$ by PPD and rHBHA-FAP within the control group (Fig. 2), levels of IFN- $\gamma$ after the second booster was increased significantly in PBMCs isolated from PPD and rHBHA-FAP vaccinated goats stimulated with PPD and rHBHA-FAP (Figs. 3, 4). The response was further enhanced after the third and fourth booster in test group (Fig. 4). The highest level of secreted IFN- $\gamma$ of PBMCs stimulated with PPD was observed in week three (after second booster) in positive control group (Fig. 3).

In test group, statistically significant difference between stimulated PBMCs by PPD and rHBHA-FAP was observed just in week 5 (Fig. 4); but in control positive group, the differences of IFN- $\gamma$ level was statistically significant after the first vaccination (week 2, 3, 4, and 5) (Fig. 3).

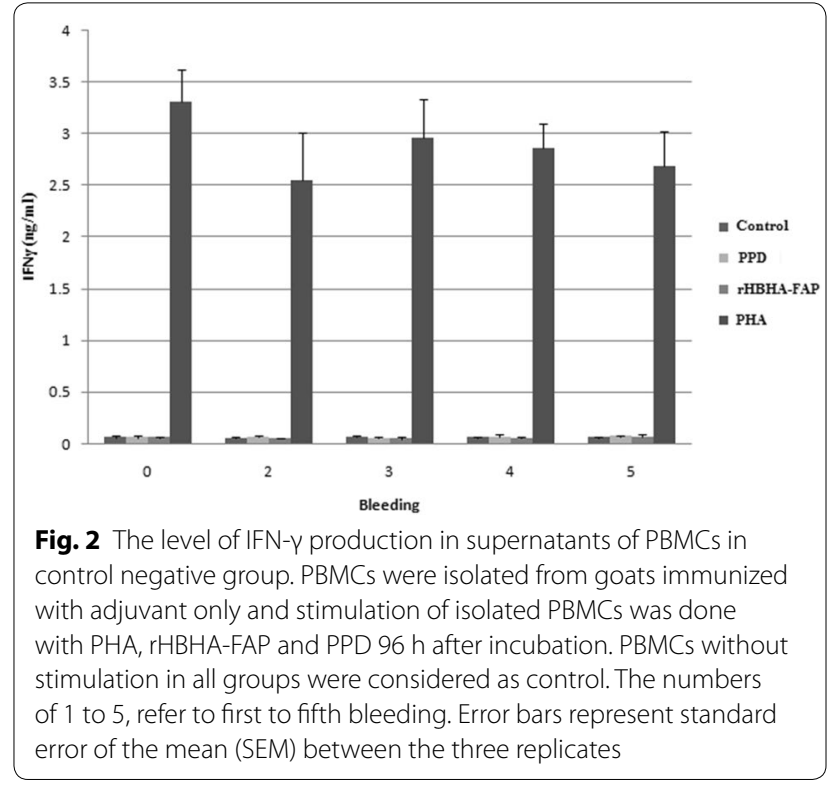

\section{Discussion}

Since MAP causes Johne's disease with severe economic losses and zoonotical potential of the bacteria, control strategies are essential. Between control strategies, vaccination is the best [13] and attempts have been made to introduce appropriate antigens as vaccine candidates. MAP is an intracellular bacterium that can infect macrophages. It is therefore expected to stimulate 


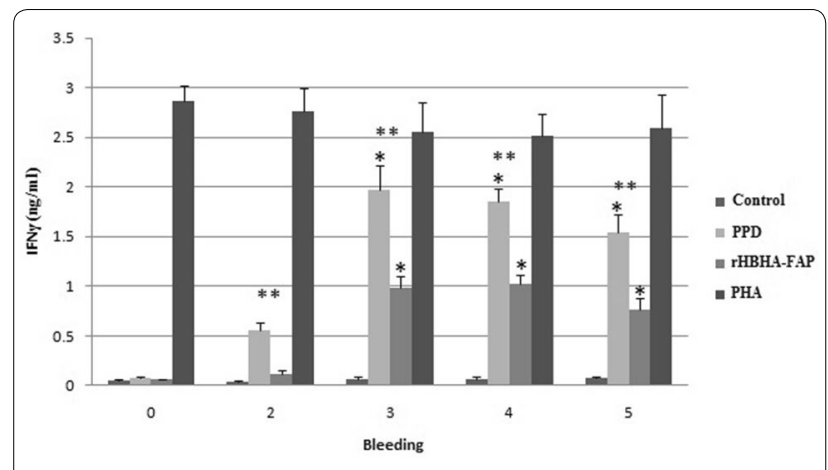

Fig. 3 The level of IFN- $\gamma$ production in supernatants of PBMCs in control positive group. PBMCs were isolated from goats immunized with PPD + adjuvant 1:1 (v/v) and stimulation of isolated PBMCs was done with PHA, rHBHA-FAP and PPD $96 \mathrm{~h}$ after incubation. PBMCs without stimulation in all groups were considered as control. The numbers of 1 to 5, refer to first to fifth bleeding. Error bars represent standard error of the mean (SEM) between the three replicates. ${ }^{*} \mathrm{~A}$ statistically significant change as compared to the control of the same group at $p<0.05 .{ }^{* *} \mathrm{~A}$ statistically significant difference between stimulated PBMCs by PPD and rHBHA-FAP at $p<0.05$

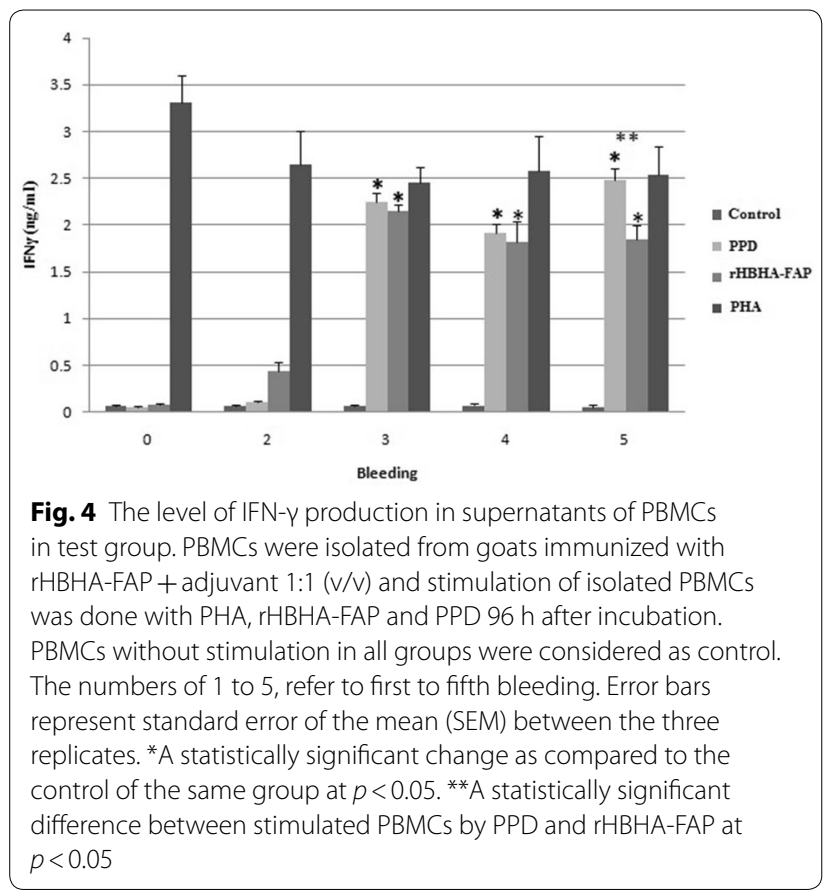

cell-mediated immunity and thus cooperate in preventing disease progression [16, 25]. Then, research about the production of new recombinant proteins, evaluation of capability to IFN- $\gamma$ response induction, and immunization assay are helpful. Several proteins and several antigens were introduced as vaccine candidates and some of them were tested for their potential impact [2632]. In addition, several antigens have been reported as potent inducer of IFN- $\gamma$ production, including the secreted 14-kDa protein MPP14 [33], alkyl hydroperoxidase reductase $\mathrm{C}$ (AhpC) and $\mathrm{AhpD}$ [30], the 30-kDa antigen P30 [34], a superoxide dismutase [35], the 85B antigen [36], a thiol peroxidase [37], MAP10, MAP39 and MAP41 [29] MAP1305 [38], Ag85 [39], CobT (35$\mathrm{kDa}$ protein) [40], $70 \mathrm{kDa}$ heat shock protein [41] and malate dehydrogenase [42]. HBHA and FAP have two crucial roles in Mycobacteria: attachment and induction of cell-mediated immunity. HBHA protein has the capability of delivering the fusion protein through surface receptors on mammalian intestinal epithelial cells and Peyer's Patches. The full length of FAP-P has been demonstrated to have the potential to induce cell-mediated immunity in vitro [24] and in vivo [43]. Some studies have demonstrated that methylated HBHA causes specific IFN- $\gamma$ response in latent $M$. tuberculosis infection $[20,21]$ and the induction capability of both $\mathrm{CD}^{+}$ and $\mathrm{CD}^{+}$lymphocytes in M. tuberculosis [22]. Then, it was predicted that our chimeric protein can induce cellmediated immunity.

In the present study, successful expression and purification of the chimeric protein consisting of HBHA and high antigenic region of FAP-P, and evaluation of its IFN $-\gamma$ response induction capability in PBMCs isolated from goat models, were primarily performed. To determine whether the goat immunized with the rHBHA-FAP could induce cell mediated immunity and respond to MAP, antigen specific IFN- $\gamma$ responses were measured by ELISA. The highest level of IFN- $\gamma$ was measured in supernatants of PBMCs stimulated by PHA, which indicates the ability of stimulated T-cells in secreting significant high level of IFN- $\gamma$.

To check the specific response and level of secreted IFN- $\gamma$ against rHBHA-FAP, immunization of goats with PPD was done to create memory $\mathrm{T}$ cell against all proteins of MAP.

Stimulated PBMCs isolated from pre-immunized goats and control negative group (immunized with adjuvant only) by chimeric protein and PPD did not secrete IFN- $\gamma$ using ELISA. The IFN- $\gamma$ production level of isolated PBMCs from test group and stimulated by chimeric protein was significantly higher than the control of the same group. Also, the differences between the level of IFN- $\gamma$ was not significant between PBMCs stimulated by PPD and rHBHA-FAP except in week five. These results showed the high antigenicity of our chimeric protein as compared to stimulation of cells by crude protein fraction prepared from the culture supernatant of MAP (PPD).

The specificity of IFN- $\gamma$ responses was confirmed by the significant rise in IFN- $\gamma$ level after two booster injections of recombinant protein, the production of a high 
level of IFN- $\gamma$ in PPD stimulated PBMCs isolated from rHBHA-FAP vaccinated group and the production of a high level of IFN- $\gamma$ in rHBHA-FAP stimulated PBMCs isolated from PPD vaccinated group.

Antigen-specific gamma interferon (IFN- $\gamma$ ) secretion in positive group (immunized by all crude proteins of MAPPPD) against rHBHA-FAP, and test group (immunized by rHBHA-FAP) against PPD, also statistically insignificant rises between stimulation with rHBHA-FAP and PPD, suggested the potential and specificity of our chimeric protein to stimulate cell mediated immunity against MAP.

\section{Conclusions}

Collectively, our results showed that rHBHA-FAP protein is immunogenic in goats and it induces specific IFN- $\gamma$ response. Therefore, because of the particularly high induction of cell-mediated immunity by this product, immunization studies of this product should be conducted as a vaccine in vivo and in vitro.

\section{Methods \\ Bioinformatics analysis, plasmid construction and cloning methodology}

In order to the construct fusion gene, the full length of HBHA HBHA-coding sequence (KC920678) which encodes adhesive part of chimeric protein was selected. Searching the full length of FAP-P (KF021287) for distinguishing high antigenic region was done using CLC software (main workbench 5.5). Eventually, one type of rigid linker between these two corresponding genes was determined in such a way that the 3D structure of HBHA was similar to its native form using TM-align (http://zhang lab.ccmb.med.umich.edu/TM-align). The final fusion gene was synthesized and inserted in pUC57 between restriction sites of EcoRI and HindIII by GenScript Company (USA).

Escherichia coli $\mathrm{DH} 5 \alpha$ was grown at $37{ }^{\circ} \mathrm{C}$ in LuriaBertani medium (Himedia, India) for the cloning procedure. Chemical transformation of pUC57HBHA-FAP into $E$. coli $\mathrm{DH} 5 \alpha$ strain was done and recombinant transformants were selected by culturing on the LB medium supplemented with $50 \mu \mathrm{g} / \mathrm{ml}$ ampicillin. Subcloning of the fusion gene was done by digesting plasmid with EcoRI and HindIII (Roche, Germany), and ligating downstream of the T7 promoter into recipient expression vector of pET-26b $(+)$. The ligation mixture was transformed into E. coli BL21 (DE3) and eventually, colony PCR and enzymatic digestion confirmed the presence and proper orientation of the target DNA insert in plasmid construct. For negative control, the parent pET26b without insert was also transformed similarly.

\section{Expression and purification of rHBHA-FAP}

The overnight broth culture of recombinant colonies was inoculated into $200 \mathrm{ml}$ of fresh LB medium (1:100) and the culture was shaken $(150 \times g)$ until the $\mathrm{OD}_{600}$ value reached 0.6. Then, three IPTG concentrations ranging from 0.5 to $10 \mathrm{mM}(0.5,1$ and $10 \mathrm{mM})$, and two temperatures $\left(30{ }^{\circ} \mathrm{C}\right.$ and $\left.37^{\circ} \mathrm{C}\right)$, were tried in order to choose the optimum situation for expression.

Culture pellets were collected at different time points ranging from 0 to $24 \mathrm{~h}(0 \mathrm{~h}, 1 \mathrm{~h}, 2 \mathrm{~h}, 4 \mathrm{~h}$ and $24 \mathrm{~h})$.

The pellets were lysed by $50 \mu \mathrm{l} 2 \times$ sample buffer $(4 \%$ SDS, 20\% glycerol, $10 \%$ 2-mercaptoethanol, $0.004 \%$ bromphenol blue and $0.125 \mathrm{M}$ Tris $\mathrm{HCl}, \mathrm{pH}$ approx. 6.8), heated at $90{ }^{\circ} \mathrm{C}$ for $10 \mathrm{~min}$ and analyzed by running them on $12 \%$ polyacrylamide gel electrophoresis under denaturing condition and were subsequently stained with Coomassie Brilliant Blue R-250 (Merck, Germany).

By using western blot, the fusion protein was identified based on expressed histidine tag. Hence, the SDS-PAGE separated proteins were transferred onto a nitrocellulose membrane and incubated with a 1:10,000 dilution of monoclonal anti-polyhistidine-peroxidase (Sigma, USA). The color development was done by using $\mathrm{H}_{2} \mathrm{O}_{2} / \mathrm{DAB}$ substrate/chromogen (Sigma, USA).

The conserved pelleted cells in $-20{ }^{\circ} \mathrm{C}$ were resuspended in $700 \mu$ lysis buffer containing $7 \mathrm{M}$ urea, $0.1 \mathrm{M}$ sodium phosphate, and $0.01 \mathrm{M}$ Tric $\mathrm{HCl}$ at a final $\mathrm{pH}$ of 8 , and $1 \mathrm{mM}$ proteinase inhibitor of Phenylmethanesulfonyl fluoride (Sigma, USA). The mixture was incubated at room temperature (RT) for $15 \mathrm{~min}$ and then insoluble debris was removed by centrifugation at $13,000 \mathrm{~g}$ for $30 \mathrm{~min}$ at room temperature. The supernatant was added to pre-equilibrated Ni-NTA spin columns (Qiagen, Germany) and then centrifuged at $270 \mathrm{~g}$ for $10 \mathrm{~min}$. The wash procedure was done three times with $600 \mu \mathrm{l}$ wash buffer containing $8 \mathrm{M}$ urea, $0.1 \mathrm{M}$ sodium phosphate, $0.01 \mathrm{M}$ Tris.Cl, $20 \mathrm{mM}$ imidazole, $2 \%$ Tween and $20 \mathrm{mM} \beta$-mercaptoethanol at $\mathrm{pH}$ of 6.3. The recombinant fusion protein was then eluted from the resin by adding $200 \mu$ l elution buffer ( $8 \mathrm{M}$ urea, $0.1 \mathrm{M}$ sodium phosphate, $0.01 \mathrm{M}$ Tris. $\mathrm{Cl}$ and $100 \mathrm{mM}$ imidazole at $\mathrm{pH} 4.5)$ and centrifuged at $890 \mathrm{~g}$ for $2 \mathrm{~min}$. To obtain soluble recombinant fusion protein and for removing urea, the collected fractions were dialyzed against four changes in PBS over the period of $36 \mathrm{~h}$. Protein concentration was determined using the Bradford assay.

\section{Animals and immunization}

Prior to the experiment, goats aged 12 months were obtained from a local farm. Fecal samples before the immunization experiments were negative for $M$. avium subsp. paratuberculosis by PCR targeting IS900 gene. 


\section{Table 1 Schedule for vaccination and bleeding of goats}

\begin{tabular}{ll}
\hline $\begin{array}{l}\text { Time post-primary } \\
\text { vaccination (weeks) }\end{array}$ & Procedure conducted \\
\hline 0 & Vaccination, bleeding ( $5 \mathrm{ml}$, jugular vein) \\
1 & Booster vaccination \\
2 & Booster vaccination, bleeding ( $5 \mathrm{ml}$, jugular vein) \\
3 & Booster vaccination, bleeding ( $5 \mathrm{ml}$, jugular vein) \\
4 & Booster vaccination, bleeding (5 ml, jugular vein) \\
5 & Booster vaccination, bleeding ( $5 \mathrm{ml}$, jugular vein) \\
6 & Bleeding ( $5 \mathrm{ml}$, jugular vein) \\
\hline
\end{tabular}

Three goats were immunized five times, subcutaneously in the neck, at 1-week intervals, using a volume of $1 \mathrm{ml}$ of one of the following: $0.5 \mathrm{ml}$ purified protein derivative $(350 \mu \mathrm{g})(\mathrm{PPD}-\mathrm{the}$ crude protein fraction prepared from the culture supernatant of MAP) mixed $1: 1(\mathrm{v} / \mathrm{v})$ with Quil A $(2 \mathrm{mg} / \mathrm{ml})$ for positive control, $0.5 \mathrm{ml}$ distilled water mixed 1:1 (v/v) with the same adjuvant for negative control, and $200 \mu \mathrm{g}$ of chimeric protein with the same adjuvant for test. Immunization and bleeding schedule are presented in Table 1. Immunization of goats with PPD was done to create memory $T$ cell against all proteins of MAP to check the response and level of secreted IFN- $\gamma$ against rHBHA-FAP.

After the experiment, all animals were transferred to animal house of school of veterinary medicine, Shiraz University.

\section{Primary cell cultures and IFN- $\gamma$ assay}

To obtain PBMC, based on the schedule (Table 1), blood samples were taken from all goats (three samples from each group). Samples were diluted $1: 1$ with $\mathrm{Ca}^{2+}$ and $\mathrm{Mg}^{2+}$ free phosphate-buffered saline (PBS) and centrifuged (at $1000 \times g$ and $20{ }^{\circ} \mathrm{C}$ for $25 \mathrm{~min}$ ). Diluted leukocytes with PBS (1:1) were layered onto Lymphodex (Inno-Train, Germany), and centrifuged (at $800 \times g$ and $18{ }^{\circ} \mathrm{C}$ for $25 \mathrm{~min}$ ). PBMCs were recovered from the buffer interface and erythrocytes were removed by incubating the cell suspension with RBC lysis buffer for $10 \mathrm{~min}$ at RT. Afterward, the cells were washed twice with PBS and resuspended in RPMI 1640 (GIBCO) supplemented with $10 \%$ fetal calf serum, $50 \mu \mathrm{M}$ 2-mercaptoethanol, $1 \mathrm{mM}$ sodium pyruvate, $100 \mu \mathrm{g} / \mathrm{ml}$ Streptomycin, and $50 \mu \mathrm{g} / \mathrm{ml}$ Gentamycin. Finally, $200 \mu \mathrm{l}$ of cell suspension containing 450,000 cells was seeded onto 96-well flat-bottom plates.

PBMCs isolated from immunized goats of positive control (vaccinated with PPD), and negative control (vaccinated with adjuvant), and test (vaccinated with the chimeric protein) at various time points were stimulated either with chimeric protein $(10 \mu \mathrm{g} /$ $\mathrm{ml})$, PPD $(10 \mu \mathrm{g} / \mathrm{ml})$, or a selective $\mathrm{T}$ cell mitogen $(2 \%$ phytohaemagglutinin (PHA), GIBCO) in triplicates. For negative control in cell culture, the same condition of cultured cells without any stimulation was considered. Plates were incubated in $5 \% \mathrm{CO}_{2}$ at $37{ }^{\circ} \mathrm{C}$. Gamma interferon (IFN- $\gamma$ ) levels were measured in PBMC cellfree culture supernatant using commercially available ID Screen Ruminant Interferon Gamma Kit (IDvet Kit, France) in time points of 48, 72, and $96 \mathrm{~h}$ after incubation by the standard ELISA technique and according to the manufacturer's instructions. The plates were read at $450 \mathrm{~nm}$ for optical densities using microplate reader. As a linear curve $(\log -\log )$, standard curves for IFN$\gamma$, ranging from 0.25 to $1 \mathrm{ng} / \mathrm{ml}$, were constructed and cytokine concentrations of experimental samples were determined.

\section{Statistical analysis}

All replicates for each group were combined to develop a mean response and error measurements were made using the standard error of the mean method. Comparisons between individual groups at each analysis time point were made using Mann-Whitney test and the p-value of $<0.05$ was taken as statistically significant.

\section{Acknowledgements}

The authors would like to thank Dr. Mostafavi for his friendly assistance during the project and the lab technicians, especially Mr. M. R. Sorbi who helped us as the instruments operator.

\section{Authors' contributions}

VE: conceptualization, data curation, formal analysis, investigation, methodology, project administration, software, visualization and writing the manuscript. AD: conceptualization, funding acquisition, investigation, methodology, project administration, resources, supervision, validation, visualization, revising the manuscript. AH: conceptualization, funding acquisition, investigation, methodology, project administration, resources, supervision, validation, visualization. MH: conceptualization, methodology, resources, supervision, validation. LAS: conceptualization, funding acquisition, methodology, resources, supervision, validation, revising the manuscript. AMB: conceptualization, data curation, investigation, methodology, visualization. All authors read and approved the final manuscript.

Funding

This study was funded by School of Veterinary Science, Shiraz University.

\section{Availability of data and materials}

The authors confirmed that all data are fully available without restriction and all relevant data are within the paper.

\section{Ethics approval and consent to participate}

The experiment was carried out in strict accordance with the guidelines of the Animal Ethics Committee of School of Veterinary Medicine, Shiraz University (dated 20 September 2013) and all applicable guidelines for the care and use of animals were followed (Permit No: 93GCU2M163973).

\section{Consent for publication}

All authors give final approval of the version to be submitted in Gut Pathogens journal.

\section{Competing interests}

The authors declare that they have no competing interests. 


\section{Author details}

${ }^{1}$ Department of Pathobiology, School of Veterinary Medicine, Shiraz University, Shiraz 71345-1731, Iran. ${ }^{2}$ Sezione di Microbiologia e Virologia, Dipartimento di Scienze Biomediche, Università degli Studi di Sassari, 07100 Sassari, Italy.

Received: 9 April 2019 Accepted: 4 July 2019

Published online: 09 July 2019

\section{References}

1. Faisal SM, Chen J-W, Yan F, Chen T-T, Useh NM, Yan W, et al. Evaluation of a Mycobacterium avium subsp. paratuberculosis leuD mutant as a vaccine candidate against challenge in a caprine model. Clin Vaccine Immunol. 2013;20(4):572-81.

2. Gurung RB, Purdie AC, Begg DJ, Whittington RJ. In silico screened Mycobacterium avium subsp. paratuberculosis (MAP) recombinant proteins upregulated under stress conditions are immunogenic in sheep. Vet Immunol Immunopathol. 2012;149(3):186-96.

3. Ellingson JL, Anderson JL, Koziczkowski JJ, Radcliff RP, Sloan SJ, Allen SE, et al. Detection of viable Mycobacterium avium subsp. paratuberculosis in retail pasteurized whole milk by two culture methods and PCR. J Food Prot. 2005;68(5):966-72.

4. Hruska K, Bartos M, Kralik P, Pavlik I. Mycobacterium avium subsp. paratuberculosis in powdered infant milk: paratuberculosis in cattle-the public health problem to be solved. Vet Med Praha. 2005;50(8):327.

5. Sechi LA, Dow CT. Mycobacterium avium ss. paratuberculosis zoonosisthe hundred year war-beyond Crohn's disease. Front Immunol. 2015;6:96.

6. Mazzone P, Corneli S, Di Paolo A, Maresca C, Felici A, Biagetti M, et al. Survival of Mycobacterium avium subsp. paratuberculosis in the intermediate and final digestion products of biogas plants. J Appl Microbiol. 2018;125(1):36-44.

7. Kirkwood CD, Wagner J, Boniface K, Vaughan J, Michalski WP, CattoSmith AG, et al. Mycobacterium avium subspecies paratuberculosis in children with early-onset Crohn's disease. Inflamm Bowel Dis. 2009;15(11):1643-55.

8. Dow CT, Ellingson JL. Detection of Mycobacterium avium ss. paratuberculosis in Blau syndrome tissues. Autoimmune Dis. 2010;2011:127692.

9. Cossu A, Rosu V, Paccagnini D, Cossu D, Pacifico A, Sechi LA. MAP3738c and MptD are specific tags of Mycobacterium avium subsp. paratuberculosis infection in type I diabetes mellitus. Clin Immunol. 2011;141(1):49-57.

10. Pinna A, Masala S, Blasetti F, Maiore I, Cossu D, Paccagnini D, et al. Detection of serum antibodies cross-reacting with Mycobacterium avium subspecies paratuberculosis and beta-cell antigen zinc transporter 8 homologous peptides in patients with high-risk proliferative diabetic retinopathy. PLoS ONE. 2014;9(9):e107802.

11. Cossu D, Cocco E, Paccagnini D, Masala S, Ahmed N, Frau J, et al. Association of Mycobacterium avium subsp. paratuberculosis with multiple sclerosis in Sardinian patients. PLoS ONE. 2011;6(4):e18482.

12. Park H-T, Yoo HS. Development of vaccines to Mycobacterium avium subsp. paratuberculosis infection. Clin Exp Vacc Res. 2016;5(2):108-16.

13. Juste RA. Slow infection control by vaccination: paratuberculosis. Vet Immunol Immunopathol. 2012;148(1):190-6.

14. Bannantine JP, Bermudez LE. No holes barred: invasion of the intestinal mucosa by Mycobacterium avium subsp. paratuberculosis. Infect Immun. 2013;81(11):3960-5.

15. Ganusov W, Klinkenberg D, Bakker D, Koets AP. Evaluating contribution of the cellular and humoral immune responses to the control of shedding of Mycobacterium avium spp. paratuberculosis in cattle. Vet Res. 2015;46(1):62.

16. Sweeney RW. Pathogenesis of paratuberculosis. Vet Clin North Am. 2011;27(3):537-46.

17. Coussens PM, Colvin CJ, Wiersma K, Abouzied A, Sipkovsky S. Gene expression profiling of peripheral blood mononuclear cells from cattle infected with Mycobacterium paratuberculosis. Infect Immun. 2002;70(10):5494-502.

18. Koets A, Rutten V, Hoek A, van Mil F, Müller K, Bakker D, et al. Progressive bovine paratuberculosis is associated with local loss of CD4+ T cells, increased frequency of $\gamma \delta T$ cells, and related changes in T-cell function. Infect Immun. 2002;70(7):3856-64.
19. Bannantine JP, Huntley JF, Miltner E, Stabel JR, Bermudez LE. The Mycobacterium avium subsp. paratuberculosis $35 \mathrm{kDa}$ protein plays a role in invasion of bovine epithelial cells. Microbiology. 2003;149(8):2061-9.

20. Masungi C, Temmerman S, Van Vooren J-P, Drowart A, Pethe K, Menozzi FD, et al. Differential T and B cell responses against Mycobacterium tuberculosis heparin-binding hemagglutinin adhesin in infected healthy individuals and patients with tuberculosis. J Infect Dis. 2002;185(4):513-20.

21. Parra M, Pickett T, Delogu G, Dheenadhayalan V, Debrie A-S, Locht C, et al. The mycobacterial heparin-binding hemagglutinin is a protective antigen in the mouse aerosol challenge model of tuberculosis. Infect Immun. 2004;72(12):6799-805.

22. Aerts L, Selis E, Corbière V, Smits K, Van Praet A, Dauby N, et al. HBHAinduced polycytotoxic CD4 ${ }^{+} \mathrm{T}$ lymphocytes are associated with the control of Mycobacterium tuberculosis infection in humans. J Immunol. 2019;202(2):421-7.

23. Temmerman S, Pethe K, Parra M, Alonso S, Rouanet C, Pickett T, et al. Methylation-dependent T cell immunity to Mycobacterium tuberculosis heparin-binding hemagglutinin. Nat Med. 2004;10(9):935.

24. Lee JS, Shin SJ, Collins MT, Jung ID, Jeong Y-I, Lee C-M, et al. Mycobacterium avium subsp. paratuberculosis fibronectin attachment protein activates dendritic cells and induces a Th1 polarization. Infect Immun. 2009;77(7):2979-88.

25. Raupach B, Kaufmann SH. Immune responses to intracellular bacteria. Curr Opin Immunol. 2001;13(4):417-28.

26. Huntley JF, Stabel JR, Bannantine JP. Immunoreactivity of the Mycobacterium avium subsp. paratuberculosis 19-kDa lipoprotein. BMC Microbiol. 2005;5(1):3.

27. Kathaperumal K, Kumanan V, McDonough S, Chen L-H, Park S-U, Moreira $M A$, et al. Evaluation of immune responses and protective efficacy in a goat model following immunization with a cocktail of recombinant antigens and a polyprotein of Mycobacterium avium subsp. paratuberculosis. Vaccine. 2009;27(1):123-35.

28. Koets A, Rutten V, Hoek A, Bakker D, Van Zijderveld F, Müller K, et al. Heat-shock protein-specific T-cell responses in various stages of bovine paratuberculosis. Vet Immunol Immunopathol. 1999;70(1):105-15.

29. Nagata R, Muneta Y, Yoshihara K, Yokomizo Y, Mori Y. Expression cloning of gamma interferon-inducing antigens of Mycobacterium avium subsp. paratuberculosis. Infect Immun. 2005;73(6):3778-82.

30. Olsen I, Reitan LJ, Holstad G, Wiker HG. Alkyl hydroperoxide reductases C and D are major antigens constitutively expressed by Mycobacterium avium subsp. paratuberculosis. Infect Immun. 2000;68(2):801-8.

31. Rigden RC, Jandhyala DM, Dupont C, Crosbie-Caird D, Lopez-Villalobos N, Maeda N, et al. Humoral and cellular immune responses in sheep immunized with a 22 kilodalton exported protein of Mycobacterium avium subspecies paratuberculosis. J Med Microbiol. 2006;55(12):1735-40.

32. Shin SJ, Chang C-F, Chang C-D, McDonough SP, Thompson B, Yoo $H S$, et al. In vitro cellular immune responses to recombinant antigens of Mycobacterium avium subsp. paratuberculosis. Infect Immun. 2005;73(8):5074-85.

33. Olsen I, Storset A. Innate IFN- $\gamma$ production in cattle in response to MPP14, a secreted protein from Mycobacterium avium subsp. paratuberculosis. Scand J Immunol. 2001;54(3):306-13.

34. Burrells C, Inglis N, Davies R, Sharp J. Detection of specific T cell reactivity in sheep infected with Mycobacterium avium subspecies silvaticum and paratuberculosis using two defined mycobacterial antigens. Vet Immunol Immunopathol. 1995;45(3):311-20.

35. Mullerad J, Hovav A-H, Fishman Y, Barletta RG, Bercovier H. Antigenicity of Mycobacterium paratuberculosis superoxide dismutase in mice. FEMS Immunol Med Microbiol. 2002;34(1):81-8.

36. Mullerad J, Michal I, Fishman Y, Hovav A-H, Barletta RG, Bercovier H. The immunogenicity of Mycobacterium paratuberculosis 85B antigen. Med Microbiol Immunol. 2002;190(4):179-87.

37. Mullerad J, Hovav A-H, Nahary R, Fishman Y, Bercovier H. Immunogenicity of a $16.7 \mathrm{kDa}$ Mycobacterium paratuberculosis antigen. Microb Pathog. 2003;34(2):81-90.

38. Lee SJ, Noh KT, Kang TH, Han HD, Shin SJ, Soh BY, et al. The Mycobacterium avium subsp. paratuberculosis protein MAP1305 modulates dendritic cell-mediated T cell proliferation through Toll-like receptor-4. BMB Rep. 2014;47(2):115

39. Rosseels V, Marché S, Roupie V, Govaerts M, Godfroid J, Walravens K, et al. Members of the 30-to 32-kilodalton mycolyl transferase family (Ag85) 
from culture filtrate of Mycobacterium avium subsp. paratuberculosis are immunodominant Th1-type antigens recognized early upon infection in mice and cattle. Infect Immun. 2006;74(1):202-12.

40. Byun E-H, Kim WS, Kim J-S, Won C-J, Choi H-G, Kim H-J, et al. Mycobacterium paratuberculosis CobT activates dendritic cells via engagement of Toll-like receptor 4 resulting in Th1 cell expansion. J Biol Chem. 2012;287(46):38609-24.

41. Hoek A, Rutten VP, Vander Zee R, Davies CJ, Koets AP. Epitopes of Mycobacterium avium ssp. paratuberculosis $70 \mathrm{kDa}$ heat-shock protein activate bovine helper T cells in outbred cattle. Vaccine. 2010;28(36):5910-9.

42. Kim WS, Shin M-K, Shin SJ. MAP1981C, a putative nucleic acid-binding protein, produced by Mycobacterium avium subsp. paratuberculosis, induces maturation of dendritic cells and Th1-polarization. Front Cell Infect Microbiol. 2018;8:206.

43. Holsti MA, Schorey JS, Brown EJ, Allen PM. Identification of epitopes of fibronectin attachment protein (FAP-A) of Mycobacterium avium which stimulate strong T-cell responses in mice. Infect Immun. 1998;66(3):1261-4.

\section{Publisher's Note}

Springer Nature remains neutral with regard to jurisdictional claims in published maps and institutional affiliations.
Ready to submit your research? Choose BMC and benefit from:

- fast, convenient online submission

- thorough peer review by experienced researchers in your field

- rapid publication on acceptance

- support for research data, including large and complex data types

- gold Open Access which fosters wider collaboration and increased citations

- maximum visibility for your research: over $100 \mathrm{M}$ website views per year

At BMC, research is always in progress.

Learn more biomedcentral.com/submissions 